\title{
Phytoplankton and bacterioplankton biomass, production and turnover in a semi-enclosed embayment with spring tide induced upwelling
}

\author{
Chung-Chi Chen ${ }^{1, *}$, Fuh-Kwo Shiah ${ }^{2}$, Hung-Jen Lee ${ }^{3}$, Kuo-Yuan Li $^{4}$, Pei-Jie Meng ${ }^{3}$, \\ Shui-Ji Kao' ${ }^{2}$, Yu-Fang Tseng ${ }^{4}$, Chia-Lu Chung ${ }^{4}$ \\ ${ }^{1}$ Department of Life Science, National Taiwan Normal University, Taipei 11677, Taiwan \\ ${ }^{2}$ Research Center for Environment Changes, Academia Sinica, NanKang, Taipei 115, Taiwan \\ ${ }^{3}$ National Museum of Marine Biology \& Aquarium, Pingtung 944, Taiwan \\ ${ }^{4}$ Institute of Oceanography, National Taiwan University, Taipei 10617, Taiwan
}

\begin{abstract}
We examined the short time scale (i.e. hours to days) responses of phytoplankton and heterotrophic bacteria to a spring tide-driven upwelling, which is different from classical wind-driven systems, in southern Taiwan in a semi-enclosed embayment. Results showed that nitrate concentrations $\left(\mathrm{NO}_{3}^{-},<0.15\right.$ to $10.2 \mu \mathrm{M}$ ) correlated negatively with temperature (ca. 16 to $26^{\circ} \mathrm{C}$ ). Estimated $\mathrm{NO}_{3}{ }^{-}$flux upwelled from $>70 \mathrm{~m}$ was $\sim 60 \mathrm{mmol} \mathrm{N} \mathrm{m}{ }^{-2} \mathrm{~h}^{-1}$ with $<1 \%$ of it utilized by phytoplankton. Chlorophyll a concentrations doubled from 0.07 to $0.16 \mu \mathrm{g} \mathrm{l}^{-1}$ in the $9 \mathrm{~h}$ after the upwelling to maximal concentrations of $<0.30 \mu \mathrm{g} \mathrm{l}^{-1}$. Euphotic zone integrated primary production (IPP, ca. 118 to $\left.389 \mathrm{mg} \mathrm{C} \mathrm{m}^{-2} \mathrm{~d}^{-1}\right)$, and algal turnover rate $\left(\mathrm{P} \mu\right.$, ca. 0.27 to $\left.0.76 \mathrm{~d}^{-1}\right)$ responded to the upwelling $\sim 5 \mathrm{~h}$ earlier than chlorophyll. The observed uncoupling between upwelled nutrients and the low chlorophyll phenomenon might be due to quick tidal mixing and shorter residence time of the water mass ( $<1 \mathrm{~d})$ within the bay, in comparison to the algal turnover time (1.3 to $3.7 \mathrm{~d}$ ). Euphotic zone integrated bacterial production (17 to $28 \mathrm{mg} \mathrm{C} \mathrm{m}^{-2} \mathrm{~d}^{-1}$ ) and bacterial turnover rate $\left(0.6\right.$ to $\left.0.8 \mathrm{~d}^{-1}\right)$ were positively correlated with IPP, P $\mu$ and depth integrated particulate organic carbon (ca. 540 to $6575 \mathrm{mg} \mathrm{C} \mathrm{m}^{-2}$ ) concentrations, suggesting a high possibility of 'bottom-up' (organic substrate supply) control. This was confirmed by the results of 3 enrichment experiments showing that bacterial growth was $\mathrm{C}$ limited. Our study provides mechanistic information regarding the magnitude of the interaction between physical, chemical and biological processes, since the time scale adopted by this study encompasses the turnover times of auto- and heterotrophic plankton.
\end{abstract}

KEY WORDS: Dissolved inorganic nutrients $\cdot$ Chlorophyll $\cdot$ Bacterioplankton $\cdot$ POC $\cdot$ C-limitation · Upwelling $\cdot$ Tidal cycle $\cdot$ Taiwan

Resale or republication not permitted without written consent of the publisher

\section{INTRODUCTION}

Upwelling is an important marine phenomenon providing opportunities for understanding the magnitude of coupling among physical, chemical and biological processes (e.g. Grantham et al. 2004, Smith et al. 2004). The upwelling system is also one of the ecosystems that has the highest 'new or export production' leading to potentially profound effects on the regulation of the global carbon cycle (e.g. Barber \& Smith 1981, Dug- dale \& Wilkerson 1989, Chavez \& Toggweiler 1995, Murray et al. 1995). Most upwelling studies have been performed to address biological responses over time scales of days to years (e.g. Summerhayes et al. 1995). We now know that at larger time scales, physical, chemical and biological processes tend to be coupled, but this is not clear for smaller time scales (e.g. Blasco et al. 1984, Wilkerson \& Dugdale 1987, Dugdale \& Wilkerson 1989, Summerhayes et al. 1995, Wieters et al. 2003). The prime requisite for understanding the 
controlling mechanism is the determination of the spatial and temporal scales upon which these interactions take place, and it is at the smaller scales that mechanistic relationships are expressed (Dickie et al. 1987).

Coastal upwelling is mostly wind-driven, persists for days and weeks, and has a profound impact on coastal ecosystems (e.g. Wilkerson \& Dugdale 1987, Summerhayes et al. 1995, Wieters et al. 2003, Grantham et al. 2004). The upwelled water, with copious inorganic nutrients, is the driving force for most of the ecological processes in these systems. Internal tidal bores may be another important mechanism of supplying external nutrient rich and plankton rich water into coral reef or shelf regions (Rory et al. 1981, Pineda 1991, Leichter et al. 1998, Leichter et al. 2003). We performed a short time scale study (i.e. hours to days) of a coastal upwelling which was induced, in contrast to previous studies, by the combined effects of tidal flow and topography.
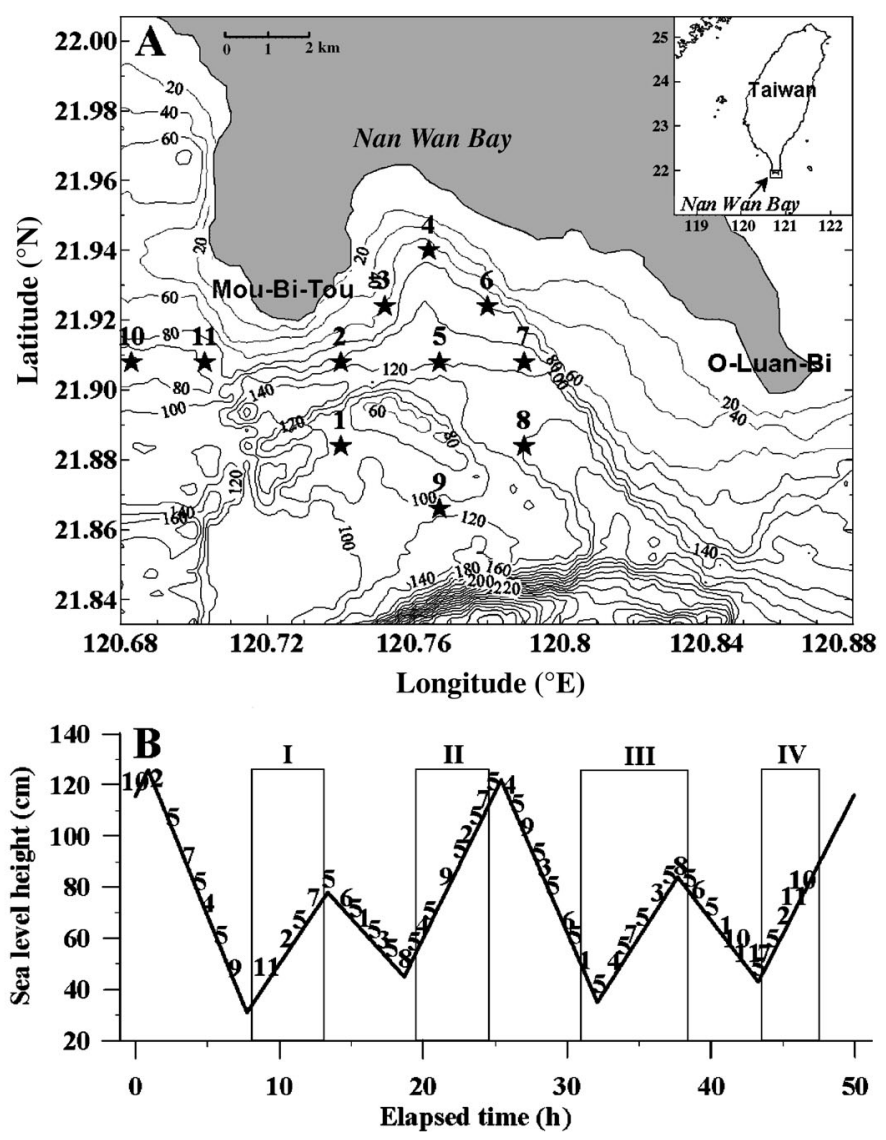

Fig. 1. (A) Map of the study area, Nan-Wan Bay in southern Taiwan, showing sampling stations and bottom topography. (B) Predicted sea level height (solid black line) and sampling sequence labeled with station numbers. I, II, III and IV indicate the sampling periods for Figs. 2A, 3A, 3B \& 2B, respectively
The study site is located in the Nan-Wan Bay in tropical southern Taiwan (Fig. 1A). It is a semi-enclosed embayment with coral reefs distributed along the coastal line at depths of $<30$ to $50 \mathrm{~m}$. There is a monthly periodic upwelling during spring tide (Lee 1999, Lee et al. 1999). Upwelling formation might be associated with cyclonic eddy pumping induced by the combined effects of tidal flow and topography. Circulation was dominated by a strong tidal current in the bay, and the prevailing tidal currents were essentially zonal and contained sizable diurnal and semidiurnal components in the study area. The duration from initiation to disappearance of this eddy pumping upwelling is $<1 \mathrm{~d}$, the maximal vertical velocity for the upwelling was $\sim 0.5 \mathrm{~cm} \mathrm{~s}^{-1}$, and the horizontal velocity of the eddy circulation could reach $\sim 70 \mathrm{~cm} \mathrm{~s}^{-1}$ (Lee et al. 1999). Interestingly, phytoplankton blooms have never been reported in this area. There are several important questions worth exploring. Does an algal bloom occur in the upper column? If not, what prevents it? How fast do auto- (primary production) and heterotrophic (bacterial production) processes couple in this system? Based on this and the above reasoning of scaling, we designed a cruise to explore how planktonic communities respond to the upwelling in shorter time scales of hours to days.

\section{MATERIALS AND METHODS}

Study area and sampling. The cruise survey was conducted on the RV 'Ocean Researcher I' in late February 2001, with 11 sampling stations in the Nan-Wan Bay (Fig. 1A). For the tidal variation study, a total of 25 continuous hydrocasts, with an interval of 1 to $2 \mathrm{~h}$, were performed at the predicted upwelling center (i.e. Stn 5). We visited Stn 5 in between each visit to all the other stations (Fig. 1B). Water samples were collected using 101 Teflon coated Go-Flo bottles mounted on a General Oceanic rosette assembly. For each station, we took water samples from 4 to 9 depths, depending on bottom depth. Temperature and salinity profiles were recorded with a SeaBird CTD (SBE 9/11 puls, SBE). For each station, there were at least 2 CTDs cast, with at least 1 cast for chemical and biological measurements (Table 1). The sampling time for each station, and the steaming time between stations were approximately 0.5 to $1.0 \mathrm{~h}$ and 10 to $20 \mathrm{~min}$, respectively. For the daytime casts, surface and subsurface photosynthetic available radiance (PAR) was recorded (QSP 160; QSR-240; QSP-200L) to calculate the euphotic zone depths (depth with $1 \%$ surface PAR) and light extinction coefficients.

Inorganic nutrients, chlorophyll $a$ and primary production. Water samples for nutrient (i.e. nitrate, phos- 


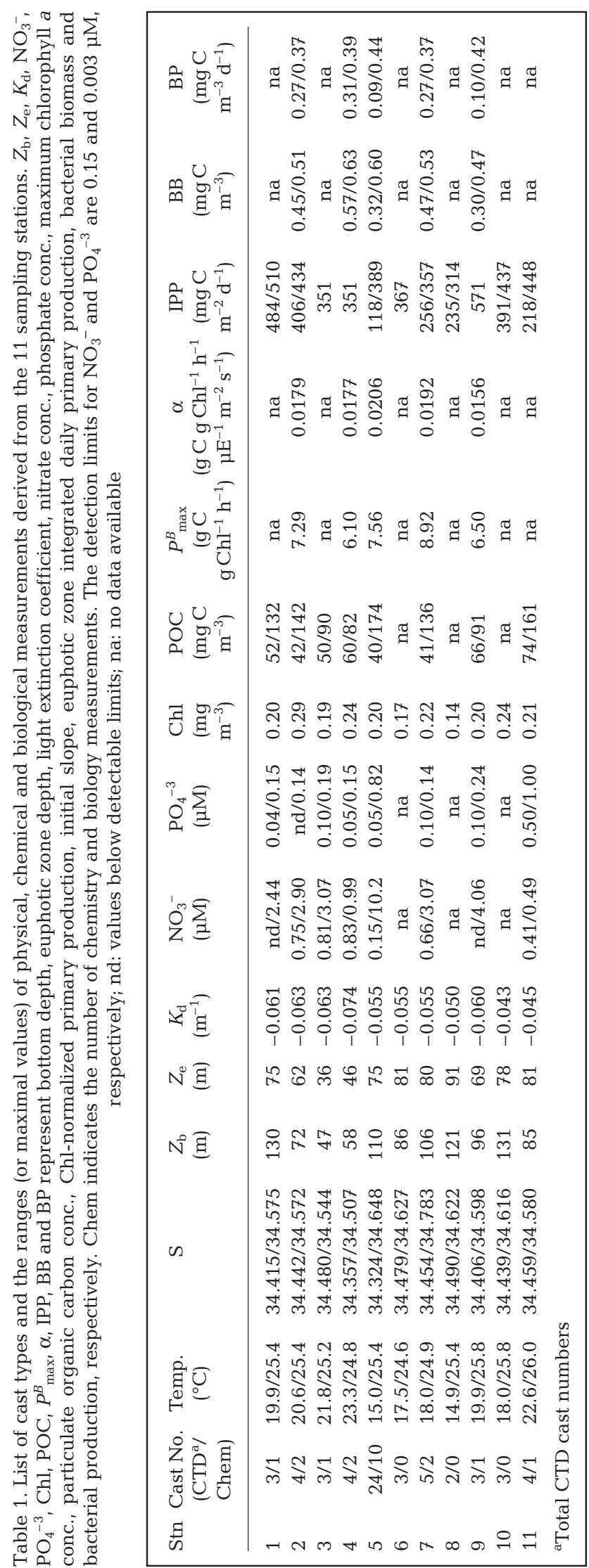

phate, and silicate) analyses were collected with $100 \mathrm{ml}$ polypropylene bottles and frozen immediately in liquid $\mathrm{N}_{2}$. A custom-made flow injection analyzer was used for nitrate and phosphate analysis (Gong 1992). Nutrients were not measured at Stns 6, 8 and 10 (Table 1). The chlorophyll a (Chl) fluorescence profile was measured with a Sea Tech fluorometer attached to a CTD. The readings of in vivo fluorescence (i.e. Fluo) were then calibrated $(\mathrm{Chl}=-0.0080+1.47 \times$ Fluo, $\mathrm{n}=$ $\left.124, \mathrm{r}^{2}=0.60, \mathrm{p}<0.001\right)$ by in vitro fluorometery (Turner Design 10-AU-005) after acetone extraction (Parsons et al. 1984).

Primary production was measured by the ${ }^{14} \mathrm{C}$ assimilation method (Parsons et al. 1984, Shiah et al. 2001). Water samples were collected from the euphotic zone, and inoculated with $\mathrm{H}^{14} \mathrm{CO}_{3}^{-}$(final conc. $10 \mu \mathrm{Ci} \mathrm{ml}{ }^{-1}$ ) in a $250 \mathrm{ml}$ clean polycarbonate bottle (Nalgene). Samples were incubated on board for 2 to $4 \mathrm{~h}$ in custom built tanks filled with running surface seawater and illuminated by fluorescent bulbs with a light intensity corresponding to the in situ irradiance level. Following retrieval, samples were immediately filtered through Whatman $25 \mathrm{~mm} \mathrm{GF/F}$ filters. The filters were then placed in scintillation vials, and $0.5 \mathrm{ml} 0.5 \mathrm{~N} \mathrm{HCl}$ was added to remove residual $\mathrm{H}^{14} \mathrm{CO}_{3}{ }^{-}$. Radioactivity was counted in a liquid scintillation counter (Packard 1600) after the addition of a $10 \mathrm{ml}$ scintillation cocktail (Ultima Gold, Packard). The model (Webb et al. 1974) was applied to estimate the maximal $\mathrm{Chl}$ normalized photosynthetic rate $\left(P_{\max }^{B}\right)$ and the initial slope $(\alpha)$. Daily primary production (PP) was then estimated using the values of the euphotic zone depth, $P^{B}{ }_{\max }, \alpha$, Chl profile, subsurface PAR profile and daytime sur-

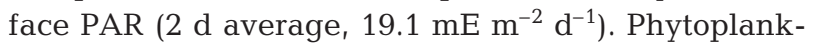
ton turnover rate was calculated as depth integrated PP divided by depth integrated Chl with a conversion factor of $58 \mathrm{~g} \mathrm{C} \mathrm{g} \mathrm{Chl}^{-1}$ (Eppley et al. 1992). PP measurements were conducted only during the daytime at Stns 2, 4, 5, 7 and 9 (Table 1). Since the $P^{B}{ }_{\max }$ and $\alpha$ derived from these stations were similar to each other (Table 1), PP for the other 6 stations were calculated using the averaged $P_{\text {max }}^{B}\left(7.27 \pm 1.09 \mathrm{~g} \mathrm{C} \mathrm{g} \mathrm{Chl}^{-1} \mathrm{~h}^{-1}\right)$ and $\alpha\left(0.0182 \pm 0.019 \mathrm{~g} \mathrm{C} \mathrm{g} \mathrm{Chl}^{-1} \mathrm{~h}^{-1} \mu^{-1} \mathrm{~m}^{-2} \mathrm{~s}^{-1}\right)$ of these 5 stations.

Particulate organic carbon, bacterial abundance and bacterial production. Samples for particulate organic carbon (POC) were filtered through a Whatman $25 \mathrm{~mm} \mathrm{GF/F} \mathrm{filter,} \mathrm{wrapped} \mathrm{in} \mathrm{aluminum} \mathrm{foil} \mathrm{and}$ then stored at $4^{\circ} \mathrm{C}$. Both filters and aluminum foil were precombusted at $550^{\circ} \mathrm{C}$ for $1 \mathrm{~h}$. After drying and acidfuming, samples were measured by the combustion method (HORIBA EMIA-510). POC was not measured at Stns 6, 8 and 10 (Table 1). Bacterial abundance was measured by acridine orange epifluorescence microscopy (Hobbie et al. 1977). Biomass was calculated 
with a carbon conversion factor of $20 \mathrm{fg} \mathrm{C}_{\mathrm{Cell}}^{-1}$ (Lancelot \& Billen 1984). Bacterial production (BP) was measured in triplicates by ${ }^{3} \mathrm{H}$-thymidine incorporation with thymidine and carbon conversion factors of $1.18 \times$ $10^{18}$ cell mol $^{-1}$ and $20 \mathrm{fg} \mathrm{C} \mathrm{cell}^{-1}$, respectively (Shiah et al. 2000). Bacterial biomass (BB) and BP data were only available for Stns 2, 4, 5, 7 and 9 (Table 1).

Bacterial enrichment experiments and data analysis. Experiments were conducted at Stns 2, 5 and 7. Water samples collected at the surface $(\sim 5 \mathrm{~m})$ were filtered through a pre-acid $(0.5 \mathrm{~N} \mathrm{HCl})$, washed, then MilliQ water rinsed through a $0.8 \mu \mathrm{m}$ polycarbonate (Nucleopore) filter. The filtrates were then assigned to 4 treatments that were incubated in duplicate 21 polycarbonate (Nalgene) bottles at in situ temperature for $12 \mathrm{~h}$. Treatments included (1) control, (2) glucose addition (C treatment), (3) $\mathrm{NH}_{4}{ }^{+}$plus $\mathrm{PO}_{4}{ }^{-3}$ addition ( $\mathrm{N}+\mathrm{P}$ treatment), and (4) glucose plus $\mathrm{NH}_{4}{ }^{+}$plus $\mathrm{PO}_{4}{ }^{-3}$ addition $(\mathrm{C}+\mathrm{N}+\mathrm{P}$ treatment). The final concentrations of glucose, $\mathrm{NH}_{4}{ }^{+}$and $\mathrm{PO}_{4}{ }^{-3}$ were $100 \mu \mathrm{M}, 1.0 \mu \mathrm{M}$ and $1.0 \mu \mathrm{M}$, respectively. Depth integrated data if used, were integrated (trapezoidal method) down to the euphotic zone depth. StatView $\mathrm{II}^{\mathrm{TM}}$ was used for statistical analysis.

\section{RESULTS}

As the Nan-Wan Bay is located in southern Taiwan, geographically, water physical properties within the bay are primarily affected by the water masses from the Western Philippine Sea (WPS) and the South China Sea (SCS, Lee 1999). The temperature-salinity diagram indicated that the temperatures and salinities taken from all sampling casts lies between those of the WPS and the SCS (data not shown). It also indicated that there was no trace of coastal and/or freshwater effects. The bottom and euphotic zone depths of the study area ranged between 47 and $131 \mathrm{~m}$ and 36 and $91 \mathrm{~m}$, respectively (Table 1 ). Light extinction coefficients ranged between -0.04 and $-0.07 \mathrm{~m}^{-1}$ with lower values observed at Stns 10 and 11 (Table 1, Fig. 1A).

During the upwelling period, i.e. from lower low water to lower high water (Fig. 1B, sampling periods I and III), the temperature profile along the transect crossing Stns 11, 2, 5 and 7 formed a dome-shape with the lowest temperature $\left(<21^{\circ} \mathrm{C}\right)$ centering at Stn 5 (Fig. 2A). During the non-upwelling period, this temperature dome-shape became much less significant (Fig. 2B). The spatial distribution of temperatures recorded at a depth of $30 \mathrm{~m}$ showed that during the non-upwelling period, its contour was less obvious, with a temperature variation $<1^{\circ} \mathrm{C}$ (Fig. 3A). During the upwelling period, the largest temperature difference between Stn 5 and the other 5 stations exceeded $3^{\circ} \mathrm{C}$ (Fig. 3B).
As to tidal variation, temperature (Fig. 4A, 15.9 to $25.1^{\circ} \mathrm{C}$ ) and salinity (Fig. $4 \mathrm{~B}, 34.32$ to 34.61 ) varied periodically within $42 \mathrm{~h}$. The $23^{\circ} \mathrm{C}$ isotherm elevated from a depth of $70 \mathrm{~m}$ to $\sim 20 \mathrm{~m}$ within $8 \mathrm{~h}$, and then descended down to $>100 \mathrm{~m}$ in $12 \mathrm{~h}$. The second cycle was more dramatic than the first one, with the $23^{\circ} \mathrm{C}$ isotherm intruding upward to a $10 \mathrm{~m}$ depth. Nitrate $\left(\mathrm{NO}_{3}{ }^{-}\right)$concentrations at Stn 5 ranged from $<0.15$ to 10.2 $\mu \mathrm{M}$ (Fig. 4C) and showed a negative correlation with temperature $\left(\mathrm{NO}_{3}{ }^{-}=26.9-1.06 \times T, \mathrm{n}=82, \mathrm{r}^{2}=\right.$ $0.92, \mathrm{p}<0.01$ ). This suggested that $\mathrm{NO}_{3}{ }^{-}$behaved reliably (i.e. no or low biological uptake or release) during the upwelling. For the 14 casts where $\mathrm{NO}_{3}{ }^{-}$concentrations were not measured, the $\mathrm{NO}_{3}{ }^{-}$profiles could be estimated from the linear relation presented above. Phosphate concentrations $\left(\mathrm{PO}_{4}{ }^{-3},<0.003\right.$ to $\left.0.82 \mu \mathrm{M}\right)$ were positively correlated with $\mathrm{NO}_{3}{ }^{-}$with an $\mathrm{N}$ :P ratio of $12.7\left(\mathrm{NO}_{3}{ }^{-}=-0.01+12.7 \times \mathrm{PO}_{4}{ }^{-3}, \mathrm{n}=82, \mathrm{r}^{2}=0.87\right.$, $\mathrm{p}<0.01$ ), which was significantly lower than the Redfield ratio $(\mathrm{N}: \mathrm{P}=16 ; \mathrm{n}=82, \mathrm{p}<0.01)$.

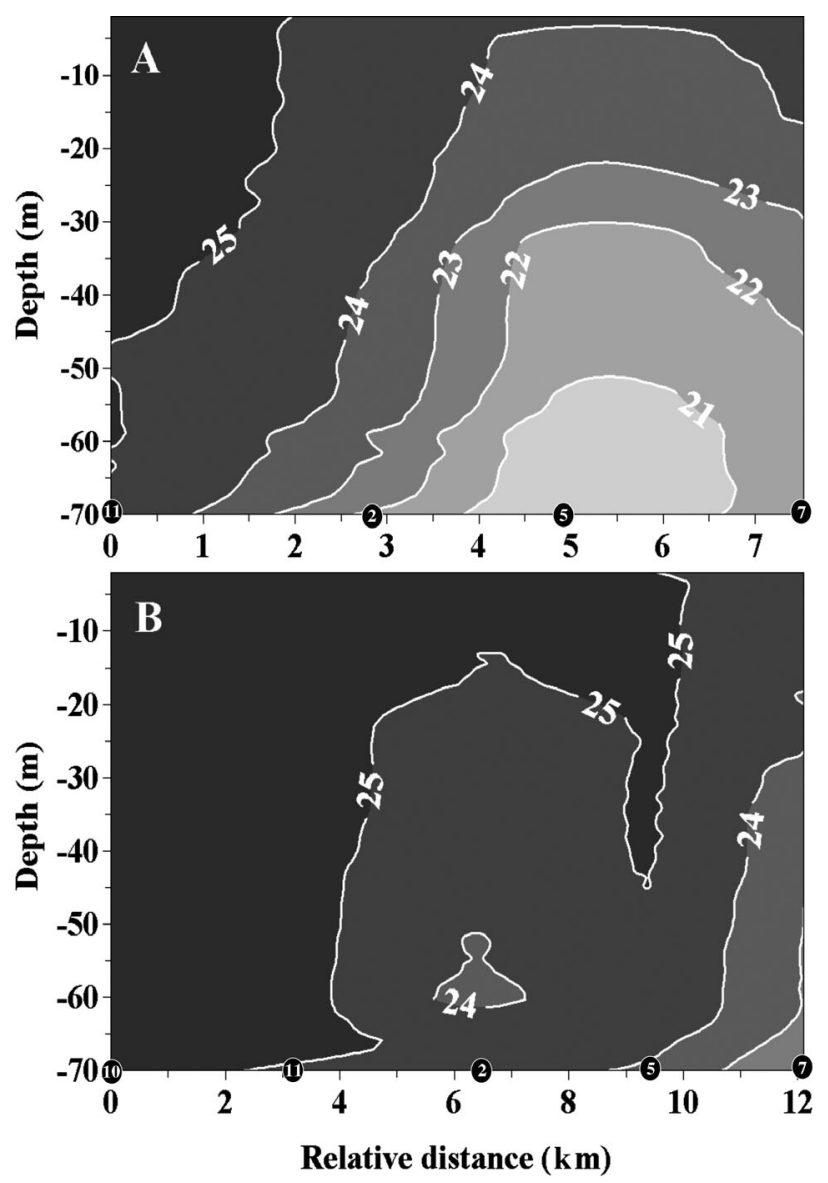

Fig. 2. Temperature contours for the transect encompassing Stns 10, 11, 2, 5 and 7. Data for (A) and (B) were taken from Sampling periods I and IV, respectively (see also Fig. 1B). The relative distance 0 was started at Stns 11 and 10 for (A) and (B), respectively 


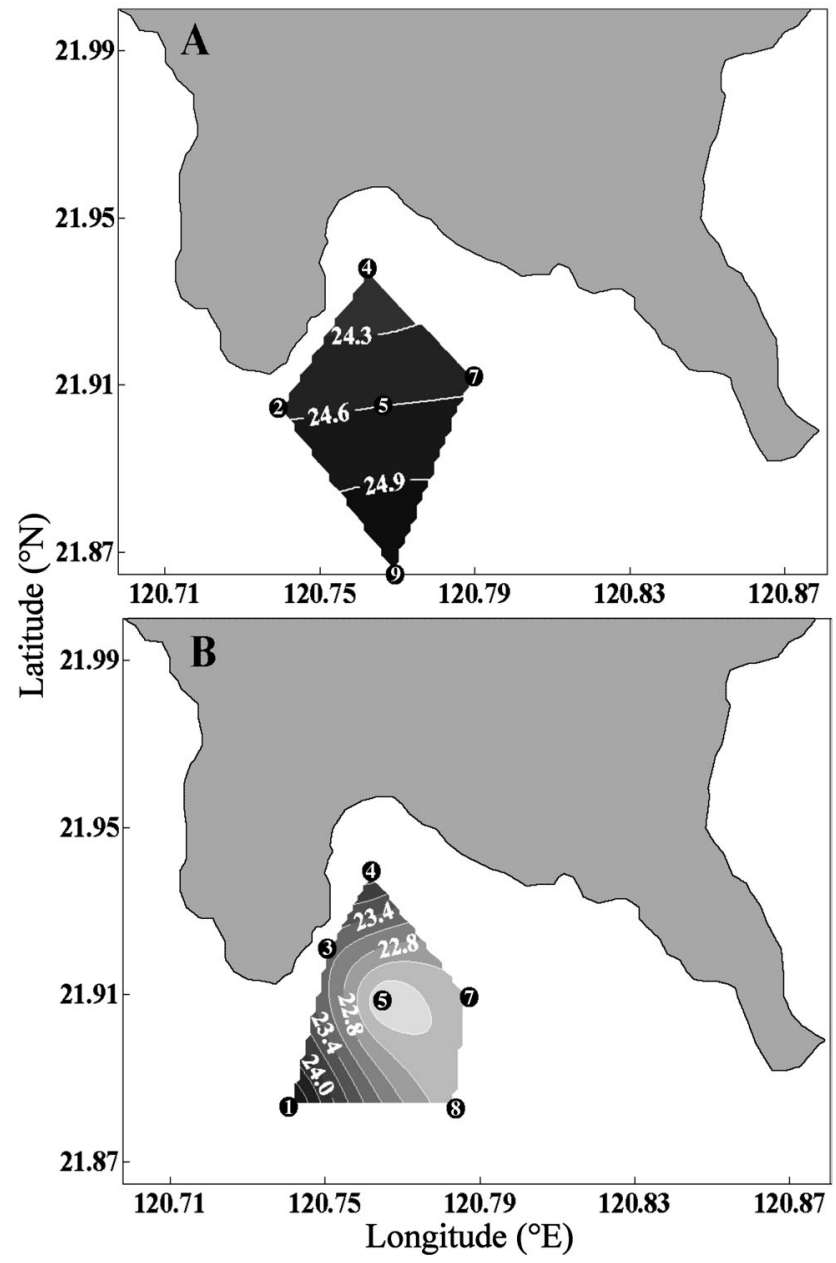

Fig. 3. Spatial patterns of temperature contour with contour interval of $0.3^{\circ} \mathrm{C}$ at a $30 \mathrm{~m}$ depth. Data for (A) and (B) were taken from Sampling periods II and III, respectively (see also Fig. 1B)

Chl concentrations ranged between $<0.1$ and $0.29 \mathrm{mg} \mathrm{Chl} \mathrm{m}^{-3}$ (Chl; Fig. 4D). The euphotic zone integrated $\mathrm{Chl}$ concentrations $\left(\mathrm{IChl}_{;} 5.2\right.$ to $11.7 \mathrm{mg} \mathrm{Chl}$ $\mathrm{m}^{-2}$ ) seemed to be out of phase with those of $70 \mathrm{~m}$ integrated $\mathrm{NO}_{3}{ }^{-}$concentrations (Fig. 5A, INO $70 ; 50$ to $\left.258 \mathrm{mmol} \mathrm{m}^{-2}, \mathrm{r}=-0.92, \mathrm{n}=25, \mathrm{p}<0.01\right)$. When $\mathrm{INO}_{70}$ reached the highest value at a sampling time of $9 \mathrm{~h}$, IChl was at its lowest. $\mathrm{INO}_{70}$ started to decrease with increasing IChl which reached a maximum at the sampling time of $18 \mathrm{~h}$. After that, IChl dropped but retained levels $>9.4 \mathrm{mg} \mathrm{Chl} \mathrm{m}{ }^{-2}$. The same phenomenon repeated after the sampling time of $28 \mathrm{~h}$. From the temporal change of $\mathrm{INO}_{70}$, we estimated the highest $\mathrm{NO}_{3}{ }^{-}$flux at Stn 5 to be $\sim 60 \mathrm{mmol} \mathrm{N} \mathrm{m}{ }^{-2} \mathrm{~h}^{-1}$. In the first tidal cycle, IChl increased from 6.7 to $11.7 \mathrm{mg} \mathrm{Chl} \mathrm{m}^{-2}$ (i.e. 0.09 to $0.16 \mu \mathrm{g} \mathrm{l}^{-1}$ ) in $9 \mathrm{~h}_{\text {; }}$ assuming phytoplankton $\mathrm{C}: \mathrm{N}$ ratios followed that of Redfield $(\mathrm{C}: \mathrm{N}=106: 16)$

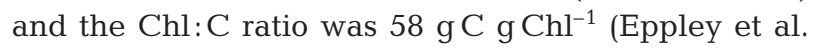

1992), the nitrate uptake rate was determined to be $0.35 \mathrm{mmol} \mathrm{N} \mathrm{m}^{-2} \mathrm{~h}^{-1}$. This accounts for $0.6 \%$ of the $\mathrm{NO}_{3}{ }^{-}$flux from the upwelling.

The euphotic zone integrated primary production (Fig. 5B, IPP; $118-389 \mathrm{mg} \mathrm{C} \mathrm{m}^{-2} \mathrm{~d}^{-1}$ ), and its turnover rates (Fig. $5 \mathrm{C}, \mathrm{P} \mu=\mathrm{IPP} / \mathrm{IChl} ; 0.27$ to $0.76 \mathrm{~d}^{-1}$ ) varied $\sim 3$-fold and seemed to respond to the upwelling $\sim 5 \mathrm{~h}$ earlier than the IChl. IPP was positively correlated with $\mathrm{P} \mu(\mathrm{r}=+0.85, \mathrm{n}=12, \mathrm{p}<0.01)$. The first maximal IPP (and $\mathrm{P} \mu$ ) appeared at the sampling time of $14 \mathrm{~h}$, i.e. $\sim 09: 30 \mathrm{~h}$, when $\mathrm{INO}_{70}$ dropped to an intermediate value of $139 \mathrm{mmol} \mathrm{m}^{-2}$. Both IPP and P $\mu$ were increasing between the 10 and $20 \mathrm{~h}$ sampling times. After

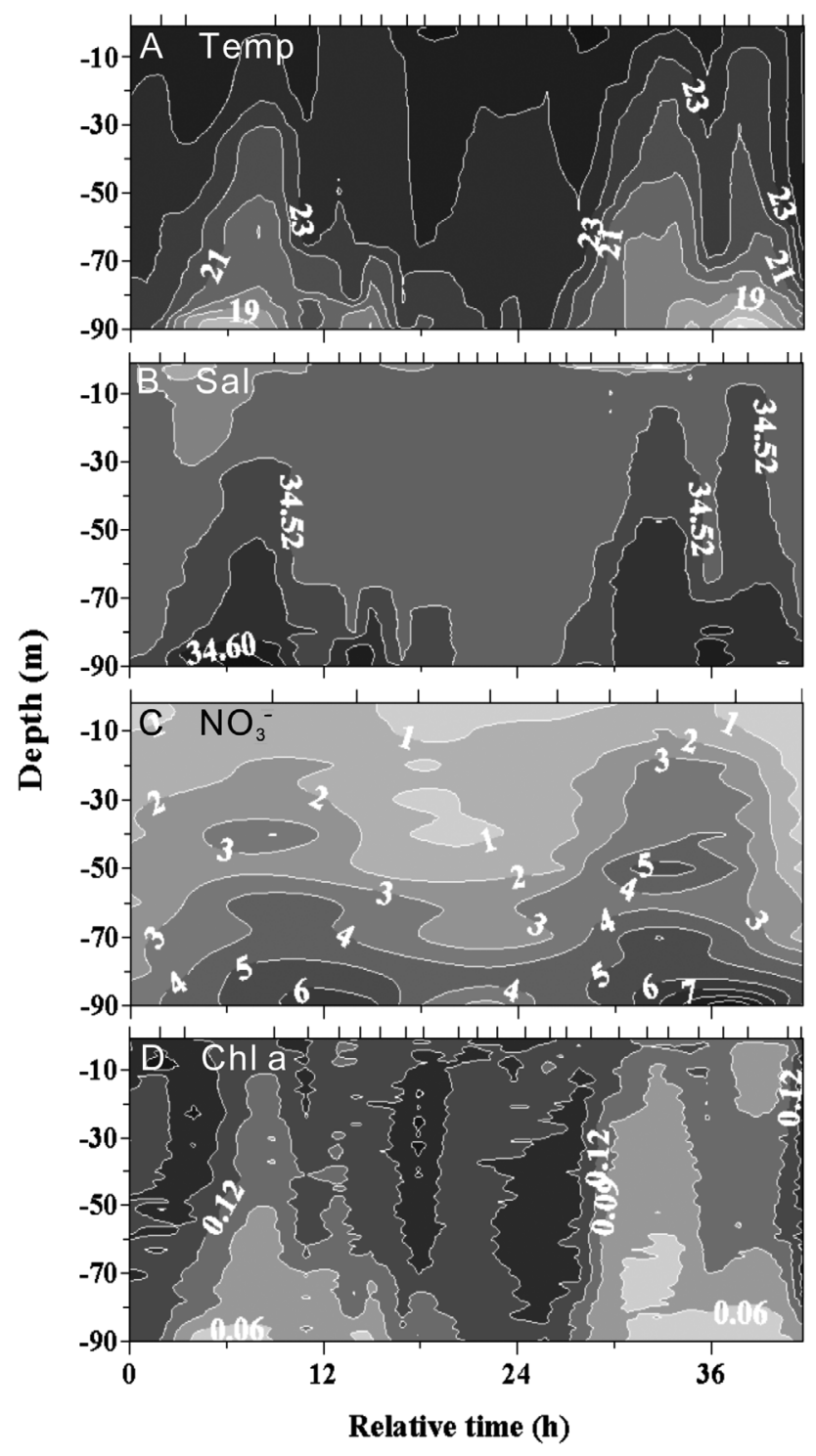

Fig. 4. Time-series contours recorded at Stn 5. (A) Temperature $\left({ }^{\circ} \mathrm{C}\right)$, (B) salinity, (C) nitrate concentrations $(\mu \mathrm{M})$, and (D) chlorophyll a concentrations $\left(\mathrm{mg} \mathrm{Chl} \mathrm{m}^{-3}\right)$. Vertical bars above each panel indicate sampling times 

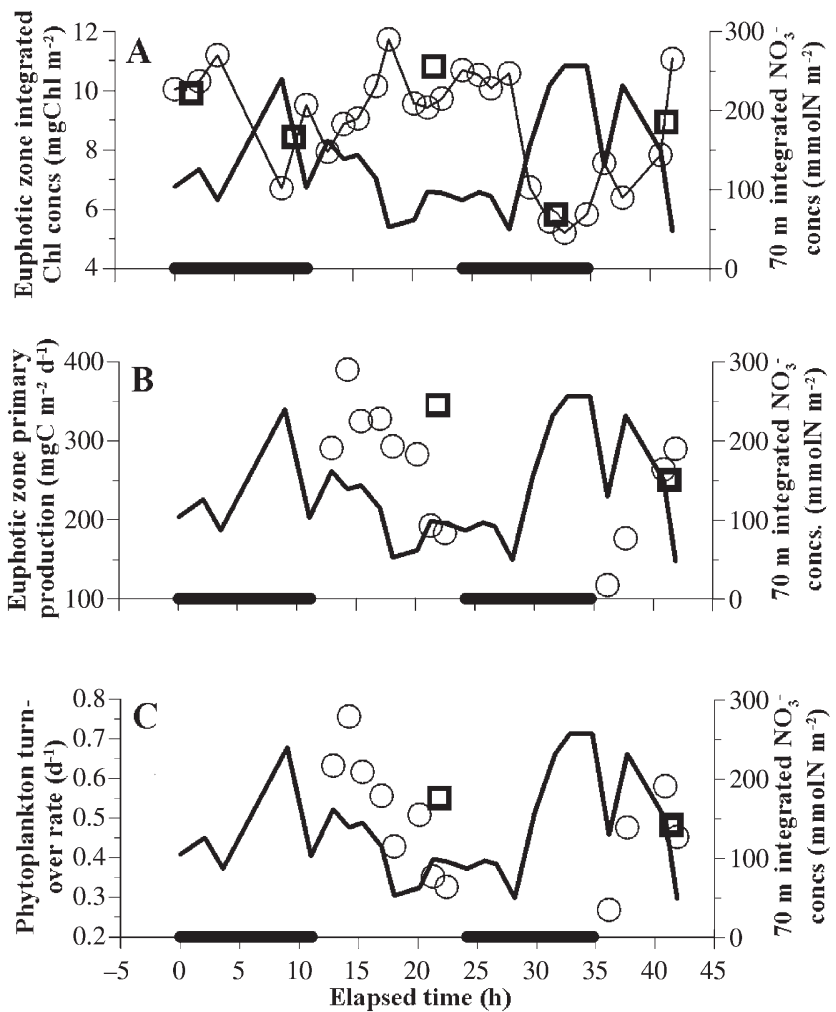

Fig. 5. Time-series plots for $70 \mathrm{~m}$ integrated nitrate concentrations $\left(\mathrm{INO}_{70}\right.$, solid line) versus (A) euphotic zone integrated Chl concentrations, (B) phytoplankton primary production, and (C) phytoplankton turnover rates recorded at Stns 5 (O) and 7 (ㅁ). Black bars on $x$-axes indicate nighttime

that, both parameters kept decreasing when surface waters were depleted of nutrients (Fig. 4C). Note that in calculating the IPP of different daytime samples, we used the same parameters derived from the $P^{B}-E$ curve of Stn 5 and the same daytime surface PAR (19.1 mE $\mathrm{m}^{-2} \mathrm{~d}^{-1}$ ). Assuming the phytoplankton C:N uptake ratio follows that of Redfield and that there are 12 daylight hours, the maximal IPP was $\sim 0.35 \mathrm{mmol} \mathrm{N} \mathrm{m}^{-2} \mathrm{~h}^{-1}$. Note that this value was exactly the same as the one calculated from the IChl data. The negative relationship for $\mathrm{INO}_{70}$ versus IChl was also observed at Stn 7 ( $\mathrm{r}=-0.94, \mathrm{n}=5, \mathrm{p}<0.01)$. In fact, the 5 data points of $\mathrm{INO}_{70}$ and IChl calculated from Stn 7 fit very well with the $\mathrm{INO}_{70}$ and IChl curves of Stn 5 (Fig. 5A).

Bacterial biomass ranged between 0.30 and $0.63 \mathrm{mg} \mathrm{C} \mathrm{m}^{-3}$ with an average of $0.46 \pm 0.09 \mathrm{mg} \mathrm{C} \mathrm{m}^{-3}$ (Fig. 6A). For most sampling stations, BB decreased with depth. The highest and lowest BB values were observed at Stns 4 and 9. Bacterial production varied several times (BP, 0.13 to $0.74 \mathrm{mg} \mathrm{C} \mathrm{m}^{-3} \mathrm{~d}^{-1}$ ) with higher values at the surface decreasing with depth (Fig. 6B). Particulate organic carbon (POC) concentrations varied 3-fold among stations ranging from 41 to
$145 \mathrm{mg} \mathrm{C} \mathrm{m}{ }^{-3}$ (Table 1). There was no consistent pattern for POC profiles (data not shown). The values of euphotic zone integrated BB (IBB, 27.7 to $36.7 \mathrm{mgC}$ $\mathrm{m}^{-2}$ ) showed no correlation with any physical or measured variables. On the other hand, the euphotic zone integrated BP (IBP, 27.7 to $46.5 \mathrm{mg} \mathrm{C} \mathrm{m}^{-2} \mathrm{~d}^{-1}$ ) and bacterial turnover rates $\left(\mathrm{B} \mu=\mathrm{IBP} / \mathrm{IBB}, 0.95\right.$ to $\left.1.38 \mathrm{~d}^{-1}\right)$ were positively correlated with euphotic zone integrated POC (IPOC, 3125 to $9163 \mathrm{mg} \mathrm{C} \mathrm{m}^{-2}$ ), IPP and P $\mu$ (Table 2). Note that for these analyses, we used data taken from different stations and sampling times.

Field data for the 3 enrichment experiments performed at Stns 2, 5 and 7 are listed in Table 3. Water samples were measured for temperature $\left(>23.0^{\circ} \mathrm{C}\right)$, salinity (>34.47), $\mathrm{NO}_{3}{ }^{-}(0.83$ to $1.24 \mu \mathrm{M})$ and $\mathrm{PO}_{4}{ }^{-3}$ $(0.10$ to $0.14 \mu \mathrm{M})$. Results for the 3 enrichment experiments were identical (Fig. 7). Taking Stn 2 as an example, the BP of the $\mathrm{N}+\mathrm{P}$ treatment showed no difference from the control treatment $\left(<0.01\right.$ to $0.018 \mathrm{mg} \mathrm{C} \mathrm{m}^{-3}$ $\mathrm{h}^{-1}$ ) over a $12 \mathrm{~h}$ incubation. BP in the glucose treatment at sampling hour $6\left(0.052 \mathrm{mg} \mathrm{C} \mathrm{m}^{-3} \mathrm{~h}^{-1}\right)$ was 4 -fold that

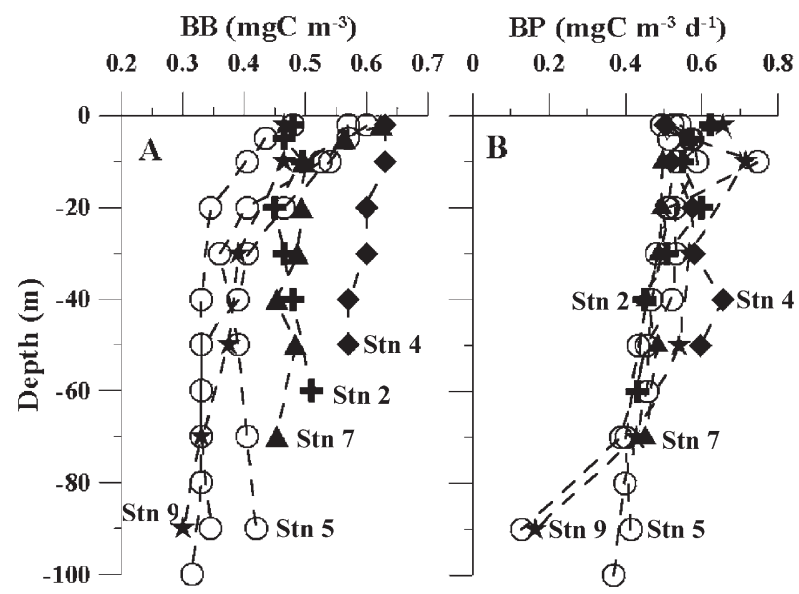

Fig. 6. Depth profiles of bacterial (A) biomass and (B) production measured at the center of upwelling (Stn 5) and Stns $2,4,7$ and 9

Table 2. Correlation coefficients among chemical and biological measurements. IPOC, IPP, IChl, IBB, IBP represent euphotic zone integrated particulate organic carbon concentrations, primary production, Chl concentrations, bacterial biomass and bacterial production, respectively. $\mathrm{P} \mu$ and $\mathrm{B} \mu$, phytoplankton and bacterial turnover rates. ns indicates not significant at the $\mathrm{p}=0.05$ level

\begin{tabular}{|c|c|c|c|c|}
\hline & $\begin{array}{c}\text { IPOC } \\
\left(\mathrm{mmol} \mathrm{C} \mathrm{m}^{-2}\right)\end{array}$ & $\begin{array}{c}\text { IPP } \\
\left(\mathrm{mg} \mathrm{C} \mathrm{m}^{-2} \mathrm{~d}^{-1}\right)\end{array}$ & $\begin{array}{c}\text { IChl } \\
\left(\mathrm{mg} \mathrm{Chl} \mathrm{m}{ }^{-2}\right)\end{array}$ & $\begin{array}{c}\mathrm{P} \mu \\
\left(\mathrm{d}^{-1}\right)\end{array}$ \\
\hline IBB $\left(\mathrm{mg} \mathrm{C} \mathrm{m}^{-2}\right)$ & ns & $\mathrm{ns}$ & ns & ns \\
\hline IBP $\left(\mathrm{mgC} \mathrm{m}^{-2} \mathrm{~d}^{-1}\right.$ & -1) +0.97 & +0.79 & ns & +0.92 \\
\hline $\mathrm{B} \mu \quad\left(\mathrm{d}^{-1}\right)$ & +0.87 & +0.97 & ns & +0.97 \\
\hline
\end{tabular}


Table 3. In situ physical, chemical and biological measurements of the 3 stations where enrichment experiments were performed. See Table 1 for abbreviations

\begin{tabular}{|lcccccccc|}
\hline Stn & Cast & $\begin{array}{c}\text { Temp. } \\
\left({ }^{\circ} \mathrm{C}\right)\end{array}$ & $\mathrm{S}$ & $\begin{array}{c}\mathrm{NO}_{3}^{-} \\
(\mu \mathrm{M})\end{array}$ & $\begin{array}{c}\mathrm{PO}_{4}^{-3} \\
(\mu \mathrm{M})\end{array}$ & $\begin{array}{c}\mathrm{BP} \\
\left(\mathrm{mg} \mathrm{C} \mathrm{m}^{-3} \mathrm{~d}^{-1}\right)\end{array}$ & $\begin{array}{c}\mathrm{POC} \\
\left(\mathrm{mg} \mathrm{C} \mathrm{m}^{-3}\right)\end{array}$ & $\begin{array}{c}\mathrm{Chl} \\
\left(\mathrm{mg} \mathrm{Chl} \mathrm{m}^{-3}\right)\end{array} \begin{array}{c}\mathrm{IPP} \\
\left(\mathrm{mg} \mathrm{C} \mathrm{m}^{-2} \mathrm{~d}^{-1}\right)\end{array}$ \\
\hline 2 & 2 & 24.30 & 34.480 & 0.83 & 0.14 & 0.97 & 94 & 0.12 \\
5 & 6 & 23.41 & 34.496 & 1.33 & 0.16 & 0.91 & 71 & 0.16 \\
7 & 3 & 24.23 & 34.473 & 1.24 & 0.10 & 1.05 & 164 & 0.16 \\
\hline
\end{tabular}

of the control $\left(0.012 \mathrm{mg} \mathrm{C} \mathrm{m} \mathrm{m}^{-3} \mathrm{~h}^{-1}\right)$. The difference between the control and the glucose treatments became more and more significant after that. The $\mathrm{C}+\mathrm{N}+\mathrm{P}$ treatment behaved almost exactly the same as the glucose treatment. All of these findings suggest that bacterial growth at these 3 stations was limited by the supply of dissolved organic carbon.
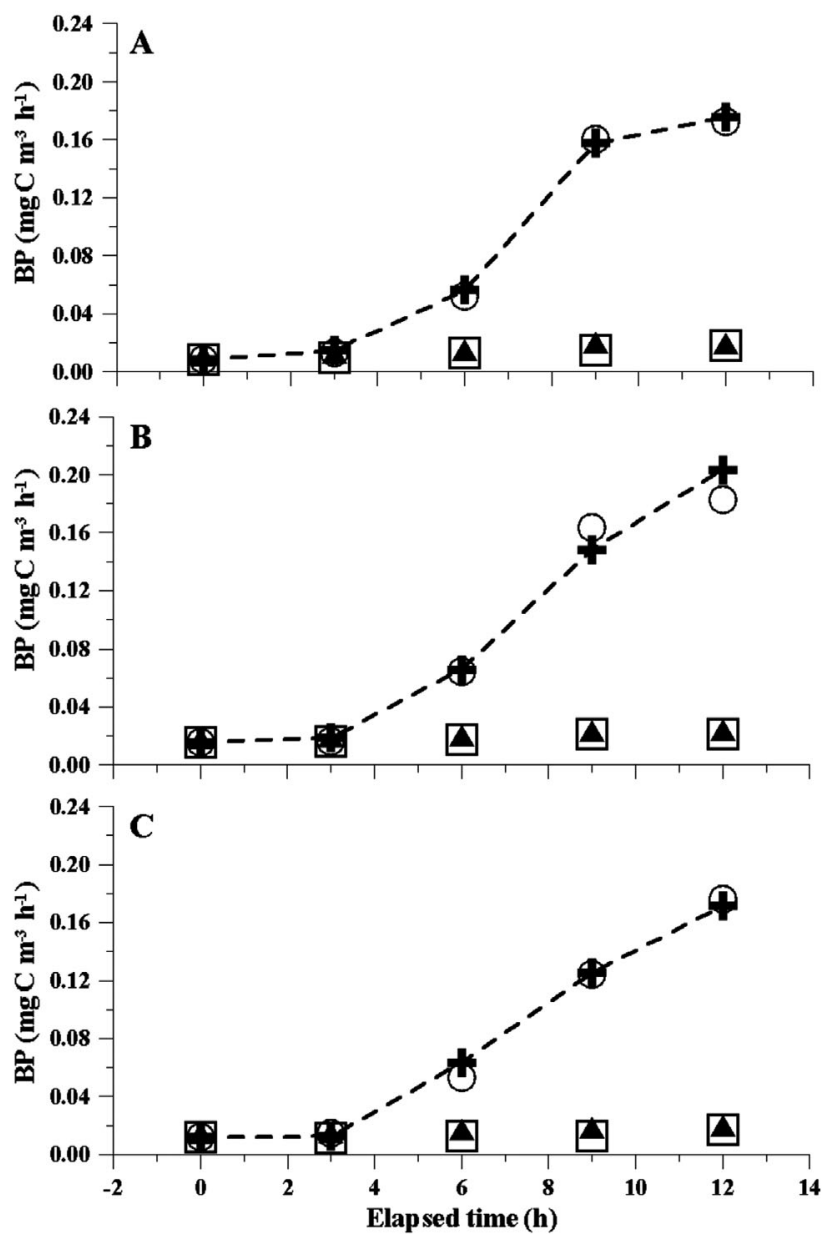

Fig. 7. Effects of dissolved organic carbon (glucose) and inorganic nutrients enrichment on bacterial production for samples taken from Stns (A) 2, (B) 5, and (C) 7. The control, glucose, $\mathrm{NH}_{4}{ }^{+}$plus $\mathrm{PO}_{4}^{-3}$ and glucose plus $\mathrm{NH}_{4}{ }^{+}$plus $\mathrm{PO}_{4}{ }^{-3}$ treatments are shown by open squares, open circles, solid triangles and crosses, respectively

\section{DISCUSSION AND CONCLUSIONS}

The enhancement of biological activity due to upwelling has been well demonstrated in several ecosystems, and upwelling was mostly driven by wind or internal tidal bores (e.g. Pineda 1991, Leichter et al. 1998, Spitz et al. 2003, Wieters et al. 2003). Few studies have focused on tide driven coastal upwelling. Results from our field study, performed at short time scales, clearly demonstrate the sequential responses of autoand heterotrophic processes to the increase of inorganic nutrients provided by tidal upwelling. The formation of the cyclonic eddy depends upon the tidal amplitude, which is at its largest during the spring tide. The disappearance of the cold and nutrient rich waters after the peak upwelling (i.e. the relaxation period of upwelling, Fig. 4, after sampling at 9 and $34 \mathrm{~h}$ ) was primarily due to quick mixing with adjacent warm (and oligotrophic) water, rather than the withdrawal of the spring tide or decrease in biological uptake. We found that there were time lags for the occurrence of maximal nutrient concentrations, phytoplankton growth and biomass accumulation (Fig. 5). In the first tidal cycle, maximal phytoplankton C-fixation and turnover rates appeared during the mid relaxation of upwelling where concentrations of $\mathrm{INO}_{70}$ were in the medium range $\left(\sim 150 \mathrm{mmol} \mathrm{N} \mathrm{m}^{-2}\right)$. Phytoplankton turnover rates $(\mathrm{P} \mu)$ decreased dramatically during the late relaxation period when $\mathrm{NO}_{3}^{-}$in the surface waters was depleted (or very low), indicating a possibility of nutrient limitation on algal growth. The same phenomenon was repeated in the second tidal cycle. Maximal algal biomass (IChl) always occurred after maximal $\mathrm{P} \mu$ (and IPP) and maintained higher values for $\sim 12 \mathrm{~h}$. This is reasonable if grazing (zooplankton) does not catch up immediately (see below). The results from Stn 7, although only based on 5 data points, also revealed the same scenario as Stn 5 (Fig. 5A).

Two interesting phenomena were noted in our field study. The decrease of inorganic nutrient concentration $\left(\mathrm{INO}_{70}\right)$ over tidal cycles seemed to be determined primarily by a physical mixing (dilution) process. Biological uptake via phytoplankton did occur but constituted $<1 \%$ of the nutrient flux $\left(\sim 60 \mathrm{mmol} \mathrm{N} \mathrm{m}^{-2}\right.$ $\mathrm{h}^{-1}$ ). This low uptake was verified independently by 
using the changes of IChl concentrations and the maximal IPP. In the tidal study, we observed that depth integrated phytoplankton biomass doubled from 5 to $12 \mathrm{mg} \mathrm{Chl} \mathrm{m}^{-2}$ (i.e. $0.05-0.16 \mathrm{mg} \mathrm{Chl} \mathrm{m}^{-3}$ ) in $9 \mathrm{~h}$, but the maximal $\mathrm{Chl}$ concentrations never exceeded $0.30 \mathrm{mg} \mathrm{Chl} \mathrm{m} \mathrm{m}^{-3}$, which is very close to the values recorded in the adjacent oligotrophic Taiwan Strait (Shiah et al. 2000). In many upwelling systems, an increase of $\mathrm{Chl}$ concentration $>1.0 \mathrm{mg} \mathrm{Chl} \mathrm{m}^{-3}$ is not uncommon (Dugdale \& Wilkerson 1989). There are 3 possibilities for this. Firstly, the low N:P molar ratio $(\mathrm{N}: \mathrm{P}=12.7)$ suggests that phytoplankton growth, and thus its biomass accumulation, might be $\mathrm{N}$ limited during the late relaxation period. Unfortunately we did not find evidence for this deduction. Secondly, zooplankton grazing, if it catches up quickly with the algal cycle, might prevent the accumulation or even reduce algal biomass. We think this possibility is small. During the second (and the first) upwelling period, IChl dropped abruptly from 10.6 to $6.7 \mathrm{mg} \mathrm{Chl} \mathrm{m}^{-2}$ in $2 \mathrm{~h}$, which is equal to a reduction rate of $18 \% \mathrm{Chl} \mathrm{h}^{-1}$ (i.e. $[10.6-6.7] /[10.6 \times 2])$. The impact of zooplankton grazing (on phytoplankton) on the study area varies between 0.13 and $0.27 \% \mathrm{Chl} \mathrm{h}^{-1}$ with an annual mean of $0.20 \% \mathrm{Chl} \mathrm{h}^{-1}$ (Dr. J. S. Hwang, unpubl. data). Therefore, grazing alone cannot account for this reduction of IChl. It has been suggested that benthic filter-feeders (i.e. sponges, soft corals, etc.) may consume a significant amount of phytoplankton (Fabricius $\&$ Dommisse 2000, Richter et al. 2001). The eddy can, in fact, reach the coral reef area with a velocity $>60 \mathrm{~cm}$ $\mathrm{s}^{-1}$ (Lee et al. 1999) and spur on the growth of phytoplankton there. Heavy grazing may reduce $\mathrm{Chl}$ concentrations in the shallow area and then transport this low Chl to the deep area by eddy movement. Benthic grazing may thus serve as one of the explanations for the reduction of $\mathrm{Chl}$ we observed in the deepwater stations. Unfortunately, we did not have enough data to verify this. After pooling the data of Stns 5 and 7 , we found significant linear positive and negative relationships for IChl versus euphotic zone averaged temperatures $\left(21.6\right.$ to $24.9^{\circ} \mathrm{C}, \mathrm{r}=+0.92, \mathrm{n}=32, \mathrm{p}<$ 0.01 ), and IChl versus euphotic zone averaged salinities (34.49 to $34.54, \mathrm{r}=-0.91, \mathrm{n}=32, \mathrm{p}<0.01$ ), respectively. This indicates that the temporal and spatial patterns of IChl might be strongly determined by conservative mixing.

The IChl recorded during the first late relaxation period (Fig. 5A, sampling hours 18 to 27) did not change much, maintaining values $>9 \mathrm{mg} \mathrm{Chl} \mathrm{m}^{-2}$. As mentioned above, we ascribed this unvaried IChl more to the reduction of $\mathrm{P} \mu$ than to zooplankton grazing. These measurements indicate that the magnitude of physical mixing is probably more important in determining the temporal and spatial patterns of phyto- plankton biomass at short time scales. That is, $\mathrm{Chl}$ is diluted during upwelled periods and starts to grow when the water column becomes more stable during early relaxation periods. When nutrients are depleted afterwards, phytoplankton growth (turnover) rates begin to decrease abruptly resulting in unvaried $\mathrm{Chl}$ concentrations. The second cycle repeats these features when the next upwelling event occurs. More importantly, the residence time $(<1 \mathrm{~d})$ of the upwelled plume within the bay (Lee 1999) was shorter than that of phytoplankton turnover time (1.3 to 3.7 d, Fig. 5 C), indicating the lack of a physical mechanism for retaining phytoplankton within the bay for mass accumulation.

The IBP/IPP (i.e. BP/PP) ratios did not vary much, displaying a mean of $9.1 \pm 0.1 \%(n=7)$. These ratios were low compared with the global average of $25 \%$ (Ducklow 1999) and those of the adjacent oligotrophic Taiwan Strait waters (Shiah et al. 2000). Assuming an averaged growth efficiency of $20 \%$ (Roland \& Cole 1999) for our bacteria, bacterial carbon demand is $\sim 50 \%$ of the in situ particulate primary production in this system. Several studies showed that algal exudation (the release of photosynthetic dissolved organic matter) constitutes 10 to $14 \%$ of particulate primary production (Ducklow \& Carlson 1992). This indicates that non-phytoplankton sources of dissolved organic matter (DOM) might be important in supporting bacterial carbon demand. One non-algal DOM source may come from the benthic system, e.g. coral exudates and others (Ferrier-Pagès et al. 2000). That is, benthic DOM could be transported to the pelagic area and then fuel bacterial growth by eddy movement in our system.

Our results showed that the heterotrophic processes were tightly coupled with phytoplankton activities and IPOC (Table 2) but not with algal biomass. The positive relationship found between bacterial rate parameters (production and turnover rate) versus phytoplankton rate parameters has been traditionally cited as evidence of bottom-up (organic substrate supply) control (Cole et al. 1988). Recent studies, on the other hand, suggest that this positive relationship might be induced by co-variation, particularly in warm and oligotrophic systems where $\mathrm{NH}_{4}{ }^{+}$availability might limit bacterial and algal growth simultaneously (Shiah et al. 2001, 2003). The results of the enrichment experiments (Fig. 7) offer convincing evidence that bacterial growth was organic C limited and the positive relationship between bacterial and phytoplankton rate parameters can be explained as bottom-up control. In fact, organic C limitation on bacterial growth in reef systems has been reported (Ferrier-Pagès et al. 2000, Torréton et al. 2000). Bimonthly enrichment experiments performed afterwards also showed that, for most of the year, bacte- 
rial growth was C limited (F.-K. Shiah \& K.-Y. Li unpubl. data). We did not measure $\mathrm{NH}_{4}{ }^{+}$concentrations during the cruise, but can reasonably deduce that the upwelling might bring $\mathrm{NH}_{4}{ }^{+}$up to the surface, as shown by other upwelling studies (Dugdale \& Wilkerson 1989). It has been established that the benthos is a net source of inorganic $\mathrm{N}$ and $\mathrm{P}$ in many reef systems (Rasheed et al. 2002). Although our experiments used water samples remote from the coral reef (i.e. Stns 2, 5 and 7 with bottom depths $>70 \mathrm{~m}$ ), inorganic nutrients released from the benthos living in the shallow area still may be able to reach to the surface waters of these 3 stations through the lifting and mixing processes caused by upwelling. Therefore, it was not surprising to see organic C limitation on bacterial growth, a tight coupling of bacterial rate parameters with phytoplankton rate parameters, and IPOC in a reef system during the upwelling period.

Overall, this study shows the sequential changes of chemical, auto- and heterotrophic processes in a semienclosed embayment during 2 upwelling events over a time scale of hours to days. Unlike other upwelling systems, chlorophyll concentrations were very low despite an elevated supply of inorganic nutrients periodically in the Nan-Wan Bay system. This uncoupling of upwelled nutrients and a low chlorophyll phenomenon can be ascribed to quick tidal mixing and the short residence time (and quick dilution) of the water mass within the bay. In an upwelling system with an abundant supply of inorganic nutrients, organic carbon limitation on bacterial growth can be expected, as shown by our enrichment experiments. More than $90 \%$ of the upwelled nutrients have not been utilized by phytoplankton within the bay. These unutilized nutrients might be important in fueling local primary production once the eddy plume moves out of the bay area. Currently, most field studies are conducted over longer time scales (seasonal to annual) and larger spatial scales (several hundred $\mathrm{km}$ to basin). Studying at shorter time scale (hours to days) variations can provide more insightful mechanistic information since this concurs with plankton turnover times.

Acknowledgements. This study is part of the cooperative research program entitled 'Long-Term Ecological Research in Kenting Coral Reefs - Integration and Model Construction'. We are grateful to both Prof. K. T. Shao (Research Center for Biodiversity, Academia Sinica, Taiwan) and Prof. L. S. Fang (National Museum of Marine Biology and Aquarium, Taiwan) for initiating this research program and for their valuable suggestions on this manuscript. This research was supported by the National Science Council, Taiwan under grant Nos. NSC-90-2621-B-002-009-A10 and NSC-93-2621-B-003-002. We thank the crew of the 'Ocean Researcher I' for cruise assistance. We are also grateful to 2 anonymous reviewers for providing valuable and constructive comments on the manuscript.

\section{LITERATURE CITED}

Barber RT, Smith RL (1981) Coastal upwelling ecosystems. In: Longhurst AR (ed) Analysis of marine ecosystems. Academic Press, London, p 31-68

Blasco D, MacIsaac JJ, Packard TT, Dugdale RC (1984) Relationship between nitrate reductase and nitrate uptake in phytoplankton in the Peru upwelling region. Limnol Oceanogr 29:275-286

Chavez FP, Toggweiler JR (1995) Physical estimates of global new production: the upwelling contribution. In: Summerhayes CP, Emeis KC, Angel MV, Smith RL, Zeitzschel B (eds) Upwelling in the ocean: modern processes and ancient records. John Wiley \& Sons, New York, p 313-320

Cole JJ, Findlay S, Pace ML (1988) Bacterial production in fresh and saltwater ecosystems: a cross-system overview. Mar Ecol Prog Ser 43:1-10

Dickie LM, Kerr SR, Boudreau PR (1987) Size-dependent processes underlying regularities in ecosystem structure. Ecol Monogr 57:233-250

Ducklow HW (1999) The bacterial component of the oceanic euphotic zone. FEMS Microbiol Ecol 30:1-10

Ducklow HW, Carlson CA (1992) Oceanic bacteria production. In: Marshall KC (ed) Advances in microbial ecology. Plenum Press, New York, p 113-181

Dugdale RC, Wilkerson FP (1989) New production in the upwelling central at Point Conception, California: temporal and spatial patterns. Deep-Sea Res I 36:985-1007

Eppley RW, Chavez FP, Barber RT (1992) Standing stocks of particulate carbon and nitrogen in the equatorial Pacific at $150^{\circ}$ W. J Geophys Res 97:655-661

Fabricius KE, Dommisse M (2000) Depletion of suspended particulate matter over coastal reef communities dominated by zooxanthellate soft corals. Mar Ecol Prog Ser 196: 157-167

Ferrier-Pagès C, Leclercq N, Jaubert J, Pelegri SP (2000) Enhancement of pico- and nanoplankton growth by coral exudates. Aquat Microb Ecol 21:203-209

Gong GC (1992) Chemical hydrography of the Kuroshio front in the sea northeast of Taiwan. PhD dissertation, National Taiwan University, Taipei

Grantham B, Chan F, Nielsen K, Fox D, Barth J, Huyer A, Lubchenco J, Menge B (2004) Upwelling-driven nearshore hypoxia signals ecosystem and oceanographic changes in the northeast Pacific. Nature 429:749-754

Hobbie JE, Daley RJ, Jasper S (1977) Use of nuclepore filters for counting bacteria by fluorescence microscopy. Appl Environ Microbiol 33:1225-1228

Lancelot C, Billen G (1984) Activity of heterotrophic bacteria and its coupling to primary production during the spring phytoplankton bloom in the south bight of the North Sea. Limnol Oceanogr 29:721-730

Lee HJ (1999) Tidally induced eddies and cold water intrusion in Nan Wan Bay. PhD dissertation, National Taiwan University, Taipei

Lee HJ, Chao SY, Fan KL, Kuo TY (1999) Tide-induced eddies and upwelling in a semi-enclosed basin: Nan Wan. Estuar Coast Shelf Sci 49:775-787

Leichter JJ, Shellenbarger G, Genovese SJ, Wing SR (1998) Breaking internal waves on a Florida (USA) coral reef: a plankton pump at work? Mar Ecol Prog Ser 166:83-97

Leichter J, Stewart H, Miller S (2003) Episodic nutrient transport to Florida coral reefs. Limnol Oceanogr 48: 1394-1407

Murray JW, Johnson E, Garside C (1995) A U.S. JGOFS Process Study in the equatorial Pacific (EqPac): Introduction. Deep-Sea Res II 42:275-293 
Parsons TR, Maita Y, Lalli CM (1984) A manual of chemical and biological methods for seawater analysis. Pergamon Press, New York

Pineda J (1991) Predictable upwelling and the shoreward transport of plankton larvae by internal tidal bores. Science 253:548-551

Rasheed M, Badran MI, Richter C, Huettel M (2002) Effect of reef framework and bottom sediment on nutrient enrichment in a coral reef of the Gulf of Aqaba, Red Sea. Mar Ecol Prog Ser 239:277-285

Richter C, Wunsch M, Rasheed M, Kotter I, Badran MI (2001) Endoscopic exploration of Red Sea coral reefs reveals dense populations of cavity-dwelling sponges. Nature 413:726-730

Roland F, Cole JJ (1999) Regulation of bacterial growth efficiency in a large turbid estuary. Aquat Microb Ecol 20: 31-38

Rory OR, Thompson Y, Golding TJ (1981) Tidally induced 'upwelling' by the Great Barrier Reef. J Geophys Res 86: $6517-6521$

Shiah FK, Chung SW, Kao SJ, Gong GC, Liu KK (2000) Biological and hydrographical responses to tropical cyclones (typhoons) in the continental shelf of the Taiwan Strait. Cont Shelf Res 20:2029-2044

Shiah FK, Chen TY, Gong GC, Chen CC, Chiang KP, Hung JJ (2001) Differential coupling of bacterial and primary production in mesotrophic and oligotrophic systems of the East China Sea. Aquat Microb Ecol 23:273-282

Shiah FK, Gong GC, Chen CC (2003) Seasonal and spatial variation of bacterial production in the continental shelf of

Editorial responsibility: Jennifer Purcell (Contributing Editor), Anacortes, Washington, USA the East China Sea: a synthesis of controlling mechanisms and potential roles in carbon cycling. Deep-Sea Res II 50: 1295-1309

Smith JE, Smith CM, Vroom PS, Beach KL, Miller S (2004) Nutrient and growth dynamics of Halimeda tuna on Conch Reef, Florida Keys: possible influence of internal tides on nutrient status and physiology. Limnol Oceanogr 49:1923-1936

Spitz YH, Newberger PA, Allen JS (2003) Ecosystem response to upwelling off the Oregon coast: Behavior of three nitrogen-based models. J Geophys Res 108:3062, doi: 3010.1029/2001JC001181

Steele JH (1991) Marine ecosystem dynamics: comparison of scales. Ecol Res 6:175-183

Summerhayes CP, Emeis KC, Angel MV, Smith RL, Zeitzchel B (eds) (1995) Upwelling in the ocean: modern processes and ancient records. John Wiley \& Sons, New York

Torréton JP, Talbot V, Garcia N (2000) Nutrient stimulation of bacterioplankton growth in Tuamotu atoll lagoons. Aquat Microb Ecol 21:125-137

Webb WL, Newton M, Starr D (1974) Carbon dioxide exchange of Alnus urbra: a mathematical model. Oecologia 17:281-291

Wieters EA, Kaplan DM, Navarrete SA, Sotomayor A, Largier J, Nielsen KJ, Veliz F (2003) Alongshore and temporal variability in chlorophyll a concentration in Chilean nearshore waters. Mar Ecol Prog Ser 249:93-105

Wilkerson FP, Dugdale RC (1987) The use of large shipboard barrels and drifters to study the effects of coastal upwelling on phytoplankton dynamics. Limnol Oceanogr 32:368-382

Submitted: June 7, 2004; Accepted: June 15, 2005

Proofs received from author(s): November 2, 2005 